DOI: https://doi.org/10.32839/2304-5809/2019-4-68-49

UDC 004.652

Revin Vladyslav, Shevcheko Yuliia

National Aviation University

\title{
THE OPPORTUNITIES AND CHALLENGES OF IMPLEMENTATION OF BLOCKCHAIN IN AVIATION INDUSTRY
}

Summary. In this article are overviewed all the possibilities and problems associated with the use of blockchain in aviation. Today, many companies are trying to implement and are looking for various solutions with the help of blockchain. Because it has a unique and special system of technology. As a new technology, it generates a lot of hype, something like that when the Internet became a public network. Blockchain helps to exchange data through various channels without any changes to this data; it can store and it can not be changed after this sharing. Blockchain has the potential to permanently change the industry of aviation, but this requires the use of new opportunities and to deepen knowledge of this technology in more specific details. Blockchain technology has such benefits as: 1) data security, enabling more confidence in airline customers who can provide their data; 2) decentralization; 3) information management.

Keywords: Blockchain, technology, scalability, IATA, Internet, Ethereum, smart-contracts.

Ревін В.В., Шевченко Ю.В.

Національний авіаційний університет

\section{МОЖЛИВОСТІ ТА ВИКЛИКИ ПРИ ВПРОВАДЖЕННІ БЛОКЧЕЙНУ В АВІАЦІЙНІЙ ПРОМИСЛОВОСТІ}

Анотація. У цій статті розглядаеться усі можливості та проблеми пов'язані с застосованням блокчейну в авіації. Сьогодні багато компаній намагаються реалізовувати і шукають різні рішення за допомогою блокчейна. Тому що вона володіє унікальною і особливою системою технології. Як нова технологія, вона генеруе багато ажіотажу, щось подібне було, коли Інтернет став загальнодоступною мережею. Блокчейн допомагає обмінюватися даними через різні канали без будь-яких змін у цих даних, зберігаючи ці данні, вони вже не можуть бути зміненні після цього. Блокчейн має потенщіал для того, щоб назавжди змінити індустрію авіації, але для цього потрібно використовувати нові можливості та більш детально углублятись в аналіз ціеї технології. В першу чергу це можливо завдяки таким перевагам як: 1) безпека даних, що дає змогу мати більшу довіру у клієнтів авіалінії, які можуть надають свої дані; 2) децентралізація; 3) управління інформацією. В авіаційній сфрері вже є практичні приклади використовування блокчейну для різних операцій, від закупівлі пального для повітряних суден до продажу квитків вже кінцевим кліентам. Одним з цих прикладів є російська авіалінія Авіакомпанія «Сибір». Група Люфтханза с 2016 року проводить масштабні тестування в напрямку використання блокчейну та залучила 40 банків в розробці бізнес платформи на основі блокчейну, для створення контрактів з будь-якими агентами та кінцевими споживачами, та надання їм інформації. Ці агенти будуть надавати різни послуги: продаж авіаквитків, бронювання номерів готелю. В блокчейну е також значні недоліки, як масштабування, тобто простір цих даних. Наразі один блок обмежен в 3,5 мегабайтів. Це дає змогу робити 24 тисячі транзакцій на добу, але це дуже мала потужність для великих авіаліній та аеропортів, де завжди відбувається багато транзакцій та операцій. Також значною мірою може бути непрофесійне державне регулювання блокчейну в бізнесі, яке буде обмежувати блокчейн або взагалі його забороняти. Блокчейн потребує багато електроенергії, що може завдавати додаткових та дуже великих збитків підприемствам.

Ключові слова: Блокчейн, технологія, масшабування, IАТА, Інтернет, Ефір, розумні контракти.

$\mathrm{F}$ Tormulation of the problem. In connection with the rapid development of blockchain services, the API for the developers of blockchain systems to understand what problems they are solving with this integration, tools for statistics and monitoring of blockchain networks, there is a need to analyze the advantages and disadvantages of existing approaches and implementations for application in aviation industry. There is a need to determine the directions of development of protected corporate blockade applications and solving such issues as security, high availability and speed of scalability.

Identification of previously unsettled parts of the general problem. This article is focus on main problems of implementation of blockchain in aviation. Also, lack of investigation and analysis of blockchain in aviation.

The purposes of this article are:

- to raise knowledge and awareness of blockchain technology;
- to show advantages and disadvantages of blockchain technology;

- to show implementation and development of this technology in aviation industry.

Analysis of recent research and publications. According to IATA "Future of the Airline Industry" [1], blockchain is one of technology that rapidly growing and will have a huge influence on future development of the aviation industry. In more enthusiastic and optimistic research, done by Accenture Consulting more than $85 \%$ of aerospace and defense companies are supposed to use blockchain technology by 2021 [2]. Most of them will be private, in the purpose of defending and make it more clear, accurate and precise. Also, the concept of the first blockchain was developed in 2008 by a man known as Satoshi Nakamoto. In 2008, the peer-to-peer network ( $\mathrm{P} 2 \mathrm{P})$ electronic payment protocol was described. It is a mathematical algorithm that lets you safely and privately exchange values 
through peer-to-peer networks. The protocol, created by Nakamoto, is called "the protocol of trust". Thus, the basis was laid to for the was laid. In 2009, this technology was implemented within the framework of the digital currency - the net

Presentation of main material. Opportunities in the Aviation. The commercial aviation industry is a highly complex space, where a large of a number of entities are involved in the delivery of travel products and services, which is sometimes manifested in a single product from a customer perspective. These roles are often collaborating and partnering to be able to co-deliver value and meet the expectation of customers [1].

Main abilities of blockchain are security and the most powerful is decentralization. In addition, it makes functions and operations for users more easier with the low level of possible mistakes. Such operations are tracking the data, flight operations.

There are several applications for aviation enterprises. Among its efficiency of being decentralized, blockchain's functional component as saving information on a digital platform makes it very useful for airlines. This shared platform can be handled by the Maintenance, Repair, Overhaul (MRO) teams and original equipment manufacturers (OEM) for storing the massive data like maintenance statuses, flight records, and data from the black box, etc. Moreover, the blockchain technology applied for registration of components and recording of expenses and incomes. So airlines or aviation enterprises could integrate with its own Enterprise Resource Planning systems. These records can be used to contain accounting and finance as well as any other valuable information [1].

Challenges and problems. The problems that faced aviation today is more opportunity - to generate more profit and value. Blockchain technology can create this opportunity

First challenge is people's prejudices and social acceptance. It is important to understand that blockchain and Bitcoins are not the same thing. Bitcoin are based on blockchain technology, but there are also other variants of blockchain like Ethereum.

Blockchain is new technology that needs to be implemented, embedded, adapted and maintained.

Governmental regulation can be crucial in development of blockchain and can include:

- prohibitive measures, that is, the actions of the authorities to impose restrictive measures on any operations with digital currencies in the financial sphere and in the sphere of accepting digital currencies by trading enterprises (services);

- wider regulation (application of regulatory requirements applicable to traditional payment methods and intermediaries, as well as to cryptocurrency and blockchain infrastructure, for example consumer rights protection);

- institutional regulation of specific subjects of cryptocurrency and blockchain infrastructure;

- interpretation of existing regulation, that is, assessment of the application of existing legislation in relation to cryptocurrency and blockchain infrastructure;

- preparation of information documents with recommendations (cautions) for users and investors on the existing risks and market impact of such technologies.
Technological problems. Scalability also is the one of biggest chalanges in implementing blockchain technology. Blockchain technology is great for small data. Too large amounts of information can lead to serious problems in blockchain technologies. Client database, recording financial transactions, maintenance management, all of this required a space and can be huge problem when all of this will work together.

Purely decentralized blockchains often have a structure that hinders them from achieving high transaction speed levels. For example, recently Bitcoin's transaction rate has been around 2.8 transactions per second, but Visa handles 24,00019 transactions per second. Paypal refused to work on blockchain technology because it keeps to low number of transactions and can't handle more than 300000 (3.5 per second if block is limited by 1 megabyte) transactions per day, but Paypal regular transactions per day is 10 million.

Earlier platforms encountered similar problems. When millions of users connected to the Internet in the 1990s, skeptics predicted that his work would stop. But the internet hasn't stopped. Specialized mining computers can be very effective; more economical alternatives to the proof-of-work mechanism have been proposed. The developers are also working on a Lightning add-on that could handle many small transactions outside the blockchain. The growing speed of internet connection will allow large blocks to spread with sufficient speed.

For example, one of the directives of the European Commission (Directive 98/26EC) rightly draws attention to this aspect of the use of the blockchain such as immutability. Immutability - the main feature of blockchain, but it is not yet known how compatible this feature is with payments, where in some cases it is necessary to make changes to the registry (for example, repayments). Also this technology consumes a lot of electricity.

Blockchain is not invulnerable to malicious attacks. The theory describes models in which some groups have an incentive to attack other pools, thus significantly undermining both the short and longterm equilibrium among miners.

One of these risks is associated with the socalled " $51 \%$ attack", the possibility of which lies in the architecture of the blockchain itself. If one acting group of individuals controls at least 51\% of the computing power, such group will can reject other transaction blocks, confirming only its own, and therefore receive all newly emitted bitcoins. However, the expert argues that today the resource-intensiveness of the hash function and the emission of new bitcoins is such that $51 \%$ of the top 500 global supercomputers will not be enough to attack $51 \%$.

Blockchain use-cases in the aviation industry

1. Identity Management. In blockchain almost impossible to rewrite or delete information about the person. Every information is stored in a decentralized platform with the using biometrics, makes almost impossible to cheat. This functionality will solve the problem of identifying the possible persons, terrorists, and criminals by validating them and tracking their biometrics. Moreover, it will help to eliminate passport cheating and staff errors during the check-in phase. 
2. Ticketing with the help of tokenization. In our day airplane tickets can be paper, which is purchased in airport or electronic, which are purchased through Internet services. blockchain uses a small contract, a tokenize asset and further dematerialize it. So, there was no need to use paper tickets. Tokenized tickets can have new business logic, by using a different partner that can be sold and buy tickets in every part of the world. Do not forget about the ability to secure information and store it.

3. Security. Everyone wants to secure their personal information. Clients shared personal data like biometrics, name, phone number, address with the airlines. If industries provide will secure this information from the third parties, customers will trust more to airlines.

4. Maintenance. There are a massive work in maintenance, where need to regulate work between manufacturers, suppliers, middleman, airlines, traders. These requires a huge amount of time and there are a high risk of error, when filling database and documentation. Blockchain technology can make the use of databases easier and remove paper work and errors by providing single enable record of products with every actor of use case. The information of this record would be available for any people who have an access to this with its own log in.[2].

Russian experience of implementing the blockchain technology. In July 2016, S7 Group together with Alfa-Bank conducted the world's first sale of an air ticket through the blockchain platform.

One of the main applications of the blockchain in aviation is the distribution of tickets through an agent network. The company uses the so-called smart contracts - they ensure the closing of the transaction under certain conditions. The blockchain allows you to simplify and make as transparent as possible the work with agents selling $\mathrm{S} 7$ tickets. The time from the ticket sale to the agent to receive funds by the airline is 23 seconds, according to standard procedures, it takes 10 days - this time is spent on letters, reconciliation, transfer of funds.

In addition, agents when using the blockchain to work with S7 do not need to receive a bank guarantee or keep a deposit with the airline to guarantee payment for tickets purchased. Since the system, when selling a ticket, verifies the availability of funds at the agent in the accounts and immediately transfers them to the airline. That is, it is an advanced technological tool for direct interaction between the airline and the agent, bypassing intermediaries [3].
Previously, many agents could not work directly with S7, since they did not have the means to make a deposit and could not receive a bank guarantee. Thus, the blockchain can significantly expand the agent network and reduce the receivables of the airline. S7 does not disclose the total number of agents, including those working through the blockchain.

The blockchain platform was developed by S7 together with Alfa-Bank, now agents must have an account in it to connect. While it is difficult to say whether it can in the future become an independent line of business, now S7 charges such companies with payment for blockchain operations.

From financial and operational analysis, we can see that S7 are growing with revenue and passengers. While, ruble were losing its cost and value, revenue and profit can't be important factors to analyze, but still, from Table 1, we can see that $\mathrm{S} 7$ show positive trend with profit, when Russian aviation industry suffered. Passengers traffic in Russia were decreased in 2016 by $3,8 \%$ and in 2017 by $5 \%$, but passenger traffic of $\mathrm{S} 7$ and its share in market were increased. May be one of factor were that $n$ 2016 they started to use smart-contracts. Also, it influenced on their financial investments that has extremely grown [4].

The blockchain is effective for optimizing interaction in branched b2b systems where there are a large number of counterparties and buyers. The technology helps to link sales and settlements with agents in real time, provides for the movement of funds on real bank accounts 24/7. Blockchain, helps reduce operating costs by eliminating unnecessary and duplicate processes.

Another direction for using the blockchain is aircraft maintenance. The maintenance history and confirmation of the authenticity of spare parts are crucial for ensuring flight safety, the facts of servicing a vessel component are stored mostly in paper form, and there is a risk of losing them, and restoring is rather problematic and requires considerable labor costs.

One of the fields where it is already implemented is fuel payment. It was started by the operator of the aviation fuel market Gazpromneft-Aero, the airline S7 Airlines and Alfa Bank.

For instant payment of jet fuel at the moment of aircraft refueling, smart contracts are used on the blockchain platform Hyperledger. Refueling takes the following steps: the airline in advance sends to the fuel company data on the planned refueling of

Financial and operational analysis of S7

Table 1

\begin{tabular}{|c|c|c|c|c|c|}
\hline Year & Revenue, rub & Profit, rub & $\begin{array}{c}\text { Financial } \\
\text { investments, rub }\end{array}$ & Passengers & Fleet \\
\hline 2010 & 6432552000 & 26022000 & 223564000 & & \\
\hline 2011 & 7479860000 & 97635000 & 297429000 & & \\
\hline 2012 & 45264052000 & 733524000 & 362489000 & & \\
\hline 2013 & 55863776000 & 546378000 & 299151000 & 6952000 & \\
\hline 2014 & 70706943000 & 868745000 & 634145000 & 7800000 & 45 \\
\hline 2015 & 82214521000 & 92289600 & 1542759000 & 8200000 & 45 \\
\hline 2016 & 108110823000 & 2864996000 & 5907541000 & 9500000 & 46 \\
\hline 2017 & 117722498000 & 4030126000 & 6118251000 & 9900000 & 62 \\
\hline 2018 & 135789535000 & 4160207000 & 8030843000 & 10700000 & 66 \\
\hline
\end{tabular}

Source: designed by authors by reference [4] 
the future flight, the preliminary amount of fuel and its price are recorded in electronic documents. This information is transmitted to the driver of the tanker at the airport. After confirmation, an application is sent to the company's bank to reserve the required amount. Money is written off simultaneously with the start of refueling the aircraft, and participants in the system receive feedback on the information on closing the transaction and the necessary documents [5].

With blockchain, everything runs smoother, changing from using numerous paper-based stages to digital; the pre-payment is no longer essential, which is an operational benefit, so your costs automatically decrease, whilst your benefits increase because the airline pays for exactly the amount of fuel it needs, rather than overspending, admits CEO of Gazprom-Aero.

The blockchain is also tested by the largest aviation group in Europe - Lufthansa Group. In October 2017, Lufthansa reported that it hired the Swiss company Winding Tree with the help of 40 banks to develop a b2b platform based on blockchain tech- nology: through it, agents, even small ones with no experience in the tourism industry, will be able to directly access airline booking systems and hotels, avoiding thereby intermediaries [6].

Conclusions and suggestions. From this article, we can see how blockchain will influence on the Aviation, as it also can be applied in many different spheres of Aviation, including risk planning, Airport Collaborative Decision Making, creating an accessible database, different passenger service, like compensation, manufacturer orders, supply chain. Blockchain can help to reduce the cost of the ticket, increase the level of security and privacy, and help to simplify the process for both customer and employers in the Aviation industry. But it is important to remember that every technology need to improve and develop. Now, as blockchain is very young and raw technology, it has its own problems. Companies understand the advantages of using blockchain and the try to solve this technological problems. Another problem is state regulation, where governments can badly influence on development of this technology.

\section{References:}

1. Blockchain in Aviation White Paper. URL: https://www.iata.org/publications/Documents/blockchain-in-aviationwhite-paper.pdf

2. Blockchain technology for Airline. URL: https://www.accenture.com/us-en/insight-potential-blockchaintechnology-for-airlines

3. Blockchain technology: essence, types, use in Russian practice. URL:https://www.cbr.ru/Content/Document/ File/32967/101-103_\%D0\%9D\%D1\%83\%D1\%80\%D0\%BC\%D1\%83\%D1\%85\%D0\%B0\%D0\%BC\%D0\%B5\%D1\%82 $\% \mathrm{D} 0 \% \mathrm{BE} \% \mathrm{D} 0 \% \mathrm{~B} 2 . \mathrm{pdf}$

4. Accounting (financial) report of S7. URL: https://www.e-disclosure.ru/portal/files.aspx?id=1046\&type=3

5. Gazprom Neft and S7 Airlines. URL: https://www.gazprom-neft.ru/press-center/news/1814734/

6. Lufthansa Industry Solutions has initiated the initiative Blockchain for Aviation. URL: https://www.lufthansaindustry-solutions.com/de-en/solutions-products/aviation/generating-more-transparency-in-aviation-withblockchain-technology/ 